\title{
MICROBIAL
}

\section{IRON METABOLISM}

A COMPREHENSIVE TREATISE

Edited by J. B. Neilands

DEPARTMENT OF BIOCHEMISTRY

UNIVERSTTY OF CALIFORNIA

BERKELEY, CALIFORNIA

A C A D E M I C PRES S New York and London 1974 A Subsidiary of Harcourt Brace Jovanovich, Publishers 


\section{CONTENTS}

List of Contributors $\quad$ xi

Preface $\quad$ xv

\section{PART I INTRODUCTION}

Chapter 1. Iron and Its Role in Microbial Physiology

J. B. Neilands

I. Introduction

II. Historical Background $\quad 4$

III. Biogeochemistry of Iron $\quad \mathbf{5}$

IV. Some Physical and Chemical Properties of Iron $\quad 7$

V. Iron Content of Microorganisms 16

VI. Iron Ligand Atoms in Microorganisms and Their Function $\quad 18$

VII. Life without Iron and Functional Replacements for Iron 25

VIII. Aspects of the Comparative Biochemistry of Iron Metabolism 27

$\begin{array}{ll}\text { References } & 31\end{array}$

Chapter 2. Metabolism in Iron-Limited Growth

P. Ann Light and Roger A. Clegg

I. Introduction 35

II. Iron-Limited Growth 36

III. Practical Aspects of Iron Limitation $\quad 40$

IV. Effects of Iron Deficiency and Iron Limitation 42

$\begin{array}{ll}V . & \text { Summary }\end{array}$

References $\quad 61$

PART II TRANSPORT, BIOSYNTHESIS, AND STORAGE

Chapter 3. Iron Transport in the Enteric Bacteria

H. Rosenberg and I. G. Young

I. Introduction

II. Iron Transport Systems in Escherichia Coli 
III. Iron Transport Systems in Aerobacter aerogenes 78

IV. Iron Transport Systems in Salmonella typhimurium 79

$\begin{array}{lr}\text { V. Discussion } & 80\end{array}$

$\begin{array}{ll}\text { References } & 81\end{array}$

Chapter 4. Iron Transport in Gram-Positive and Acid-Fast Bacilli

B. R. Byers

I. Introduction $\quad 83$

II. Production of Iron-Chelating Agents by Bacillus Species 85

III. Iron Transport in Bacillus megaterium 87

IV. Iron Transport in Bacillus subtilis $\quad 98$

V. Iron Transport in Mycobacterium smegmatis 100

$\begin{array}{lr}\text { VI. Summary } & 102\end{array}$

$\begin{array}{ll}\text { References } & 104\end{array}$

Chapter 5. Biosynthesis and Mechanism of Action of Hydroxamate-Type Siderochromes

Thomas Emery

$\begin{array}{ll}\text { I. Introduction } & 107\end{array}$

$\begin{array}{ll}\text { II. Hadacidin } & 108\end{array}$

III. Ferrichrome 110

IV. Rhodotorulic Acid 114

V. Aspergillic Acid 115

VI. Mycobactin 116

VII. Regulation of Hydroxamate Synthesis 118

VIII. Hydroxamate Acids and Iron Transport 119

$\begin{array}{ll}\text { References } & 122\end{array}$

Chapter 6. Biosynthesis of Heme

Nicholas J. Jacobs

I. Introduction $\quad 125$

$\begin{array}{lr}\text { II. Heme Content of Various Microorganisms } & 127\end{array}$

III. Pathway of Heme Synthesis 134

IV. Regulation of Microbial Heme Biosynthesis 140

References $\quad 144$

Chapter 7. Ferritin and Iron Metabolism in Phycomyces

Charles N. David

I. Introduction 149

II. Purification and Properties of Phycomyces Ferritin 150 
III. Induction of Ferritin Synthesis by Iron 151

IV. Ferritin Synthesis and Localization in Spores 152

V. Ferritin and Iron Metabolism in Germinating Spores 153

$\begin{array}{ll}\text { VI. Summary } & 157\end{array}$

$\begin{array}{ll}\text { References } & 158\end{array}$

\section{PAR'T III IRON ENZYMES AND PROTEINS}

Chapter 8. Ferredoxin and Rubredoxin

$$
\text { Walter Lovenberg }
$$

I. Introduction 161

II. Historical Background 162

III. Biological Roles 163

IV. Chemical Properties of Iron-Sulfur Proteins 172

V. Some General Thoughts about Iron-Sulfur Electron Carriers 182

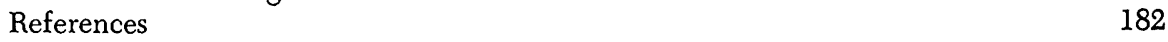

Chapter 9. Survey of Nitrogenase and Its EPR Properties

R. H. Burris and W. H. Orme-Johnson

I. Introduction

II. Isolation and Purification of Nitrogenase Components 188

III. Physicochemical Properties of Nitrogenase Components 190

IV. Catalytic Activity of Nitrogenase 193

V. EPR Studies of Nitrogenase and its Components 197

VI. Mechanism of $\mathrm{N}_{2}$ Reduction $\quad 206$

$\begin{array}{ll}\text { References } & 207\end{array}$

Chapter 10. The Nitrogen Fixation (Nif) Operon(s) of Klebsiella pneumoniae

Stanley L. Streicher and Raymond C. Valentine

I. Introduction 211

II. The Cluster of Nif Genes Near His $\quad 215$

III. Biochemical Evidence for Nitrogenase Genes Near His 218

IV. Nif- Mutations Unlinked to His 221

V. Genetic Regulation of Nif $\quad 222$

VI. Transfer of Nif to E. coli and Potential for Genetic Engineering 225 References

\section{Chapter 11. Hydrogenase}

\section{Leonard E. Mortenson and Jiann-Shin Chen}

I. Background

II. Distribution of Hydrogenase 
III. Role of Hydrogenase in Microbial Metabolism 234

IV. Nutritional Studies on Hydrogen Metabolism 249

V. Assays of Hydrogenase $\quad 253$

VI. Purification and Properties of Hydrogenase $\quad 256$

VII. Mechanism of Hydrogenase Catalysis $\quad 270$

References

\section{Chapter 12. Glutamate Synthase}

\section{Richard E. Miller}

I. Introduction $\quad 283$

II. Discovery 284

III. Distribution $\quad 285$

IV. Regulation of Glutamate Synthase Levels $\quad 286$

V. Mutants Lacking Glutamate Synthase $\quad 287$

VI. Kinetic Parameters 288

VII. Glutamate Synthesis from E. coli 289

$\begin{array}{ll}\text { VIII. Conclusions } & 301\end{array}$

$\begin{array}{ll}\text { References } & 301\end{array}$

\section{Chapter 13. Nonheme Iron in Respiratory Chains}

$$
\text { P. D. Bragg }
$$

I. Introduction 303

II. Methodology for Study of Respiratory Chain-Linked Nonheme Iron 304

III. Nonheme Iron in Respiratory Chains of Eukaryotic Cells 311

IV. Nonheme Iron in Respiratory Chains of Prokaryotic Cells 322

References

\section{Chapter 14. Cytochromes}

\section{T. Yamanaka and K. Okunuki}

I. General Survey $\quad 349$

II. Cytochrome A and Cytochrome Oxidase $\quad 355$

III. Cytochrome B 360

IV. Cytochrome C 364

V. Heme $d$-Bearing Cytochrome 388

References

\section{Chapter 15. Hydroperoxidases}

\section{Takashi Yonetani}

I. Introduction

II. Yeast Cytochrome $c$ Peroxidase 
III. Pseudomonas Cytochrome $c$ Peroxidase 406

IV. Thiobacillus Cytochrome $c$ Peroxidase $\quad 408$

V. Bacterial Catalases $\quad 410$

VI. General Discussion $\quad 412$

References $\quad 414$

Chapter 16. Oxygenases

Mitsuhiro Nozaki and Yuzuru Ishimura

$\begin{array}{ll}\text { I. Introduction } & 417\end{array}$

II. Historical Background $\quad 418$

III. Nomenclature and Classification $\quad 419$

IV. Nonheme Iron-Containing Monooxygenases 420

$V$. Nonheme Iron-Containing Dioxygenases 421

VI. Heme-Containing Oxygenases $\quad 431$

VII. Concluding Remarks $\quad 440$

References $\quad 441$

Chapter 17. Other Iron-Containing or Iron-Activated Enzymes:

Enzymes Acting on Certain Amino Acids, Amines, and Acetyl Phosphate

Richard D. Sagers

I. Introduction 446

II. Lysine 2,3-Aminomutase 446

III. L-Serine Dehydratase 448

IV. Sarcosine Dehydrogenase 449

V. Spermidine Dehydrogenase 450

VI. Phosphotransacetylase $\quad 451$

References $\quad 452$

\section{PART IV REACTIONS OF INORGANIC SUBSTRATES}

Chapter 18. The Iron-Oxidizing Bacteria

D. G. Lundgren, J. R. Vestal, and F. R. Tabita

I. Introduction $\quad 457$

II. Cultural Characteristics 458

III. Iron Oxidation and Energy Production $\quad 459$

IV. Inorganic Sulfur Oxidation 464

V. Carbon Dioxide Fixation 465

VI. Heterotrophic Metabolism 467

References $\quad 471$ 


\section{Chapter 19. Microbial Corrosion of Iron}

\section{Warren P. Iverson}

I. Historical Background

II. Economic Significance

III. Principles of Corrosion

IV. Microorganisms Involved in Corrosion of Iron

V. Mechanisms of Microbial Corrosion

VI. Prevention of Biological Corrosion

\section{PART V MEDICINE AND CHEMOTHERAPY}

Chapter 20. Bacterial Iron Metabolism in Infection and Immunity

$$
\text { J. J. Bullen, Henry J. Rogers, and E. Griffiths }
$$

I. Introduction

II. The Effects of Iron-Binding Proteins on Bacteria and Fungi in Vivo and in Vitro

III. Clinical Aspects of Altered Iron Metabolism and Infection

V. The Effects of Antibody and Iron-Binding Proteins on Bacterial Metabolism 


\section{LIST OF CONTRIBUTORS}

Numbers in parentheses indicate the pages on which authors' contributions begin.

P. D. BragG, Department of Biochemistry, University of British Columbia, Vancouver, British Columbia (303)

J. J. Bullen, National Institute for Medical Research, Mill Hill, London, England (517)

R. H. Burrus, Department of Biochemistry, College of Agricultural and Life Sciences, University of Wisconsin, Madison, Wisconsin (187)

B. R. Byers, Department of Microbiology, University of Mississippi School of Medicine, Jackson, Mississippi (83)

Jiann-Shin Chen, Department of Biological Sciences, Purdue University, West Lafayette, Indiana (231)

Roger A. Clegg, Department of Biochemistry, Medical Sciences Institute, The University, Dundee, Scotland (35)

Charles N. David, Division of Biology, California Institute of Technology, Pasadena, California (149)

Thomas Emery, Department of Chemistry and Biochemistry, Utah State University, Logan, Utah (107)

E. Griffrrms, National Institute for Medical Research, Mill Hill, London, England (517)

Yuzuru Ishimura, Department of Medical Chemistry, Kyoto University Faculty of Medicine, Kyoto, Japan (417)

Warren P. Iverson, National Bureau of Standards, Washington, D.C. (475)

Nicholas J. Jacobs, Department of Microbiology, Dartmouth University Medical School, Hanover, New Hampshire (125)

* Present Address: Department of Molecular Biology, Albert Einstein College of Medicine, Bronx, New York 


\title{
Chapter 7
}

\section{FERRITIN AND IRON METABOLISM IN PHYCOMYCES}

\author{
CHARLES N. DAVID
}

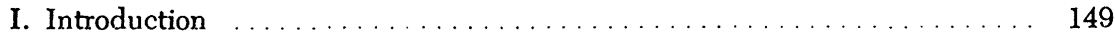

II. Purification and Properties of Phycomyces Ferritin $\ldots \ldots \ldots \ldots \ldots \ldots \ldots$

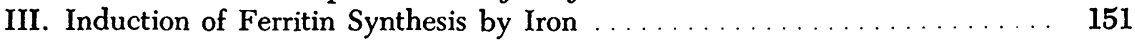

IV. Ferritin Synthesis and Localization in Spores .................. 152

V. Ferritin and Iron Metabolism in Germinating Spores . . . . . . . . . . . 153

A. The Soluble Iron Pool . . . . . . . . . . . . . . . . . . . . . 154

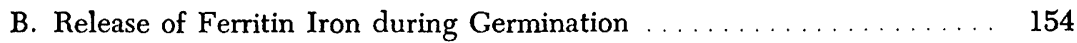

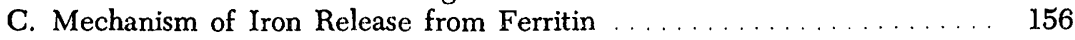

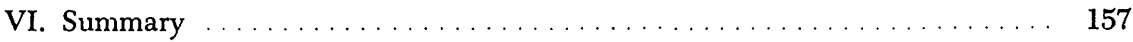

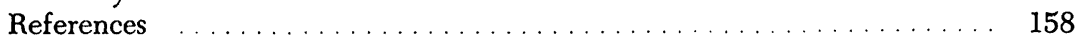

\section{INTRODUCTION}

The iron protein ferritin has recently been isolated from the fungus Phycomyces blakesleeanus (David, 1968; David and Easterbrook, 1971). Ferritin is a large molecule (MW 900,000) consisting of a shell of protein subunits surrounding a massive core of iron. The iron content of individual molecules can vary from no iron (apoferritin) to about 4000 atoms in a full core. The sedimentation coefficient varies correspondingly from 18 to $67 \mathrm{~S}$ (Fischbach and Anderegg, 1965). Although it has long been characterized in mammalian tissues (Granick, 1946; Harrison, 1964; Crichton, 1973a) and more recently in plant chloroplasts (Hyde et al., 1963), its occurrence in microorganisms was previously unknown. The present contribution summarizes briefly the characteristics of ferritin from Phycomyces and presents in some detail a series of unpublished experiments on the synthesis and degradation of ferritin and its role in iron metabolism. 


\section{PURIFICATION AND PROPERTIES OF PHYCOMYCES FERRITIN}

Ferritin in Phycomyces was initially identified in electron micrographs of thin sections of sporangiophores (Fig. 1; Sassen, 1965; Peat and Banbury, 1968; David and Easterbrook, 1971). The molecules are arranged in a two-dimensional crystalline pattern on the surface of lipid droplets in cytoplasm. The lipid droplets bearing ferritin monolayers can be isolated in the lipid pellicle following centrifugation of cell homogenates. Subsequent treatment of the lipid with detergent or $n$-butanol releases ferritin.

David and Easterbook (1971) purified and characterized ferritin from Phycomyces. Extraction of cell homogenates with $n$-butanol effectively solubilizes ferritin from lipid and precipitates most nonferritin cellular protein. Phycomyces ferritin can be purified from the aqueous phase following butanol extraction by isoelectric precipitation at $\mathrm{pH} 5.0$ and isopycnic banding in $\mathrm{CsCl}$ density gradients. Purified ferritin from Phycomcyes grown on iron-supplemented medium sediments as a single molecular species at $55 \mathrm{~S}$ and yields one band in gel electrophoresis. Removal of iron by reduction with $\mathrm{Na}_{2} \mathrm{~S}_{2} \mathrm{O}_{4}$ yields apoferritin which sediments at $18 \mathrm{~S}$. Disruption of ferritin with sodium dodecyl sulfate yields protein subunits of molecular weight 18,500 (R.R. Crichton, personal communication).

The characteristic structure of mammalian and plant ferritin revealed in the electron microscope by negative staining is also shown by Phycomyces ferritin

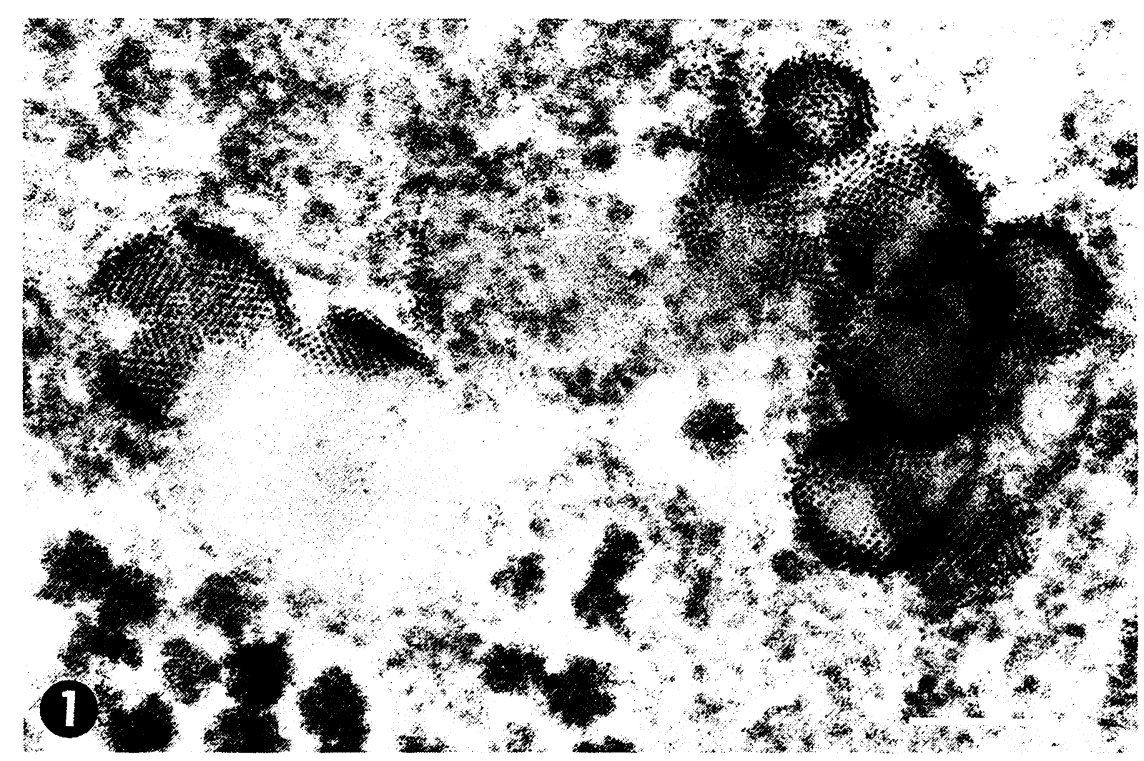

Fig. 1 Thin section of Phycomyces sporangiophore showing lipid droplets covered with crystalline arrays of ferritin molecules. Sporangiophore fixed with gluteraldehyde and osmium tetroxide. $\times 83,000$. Bar $=0.2 \mu \mathrm{m}$. 


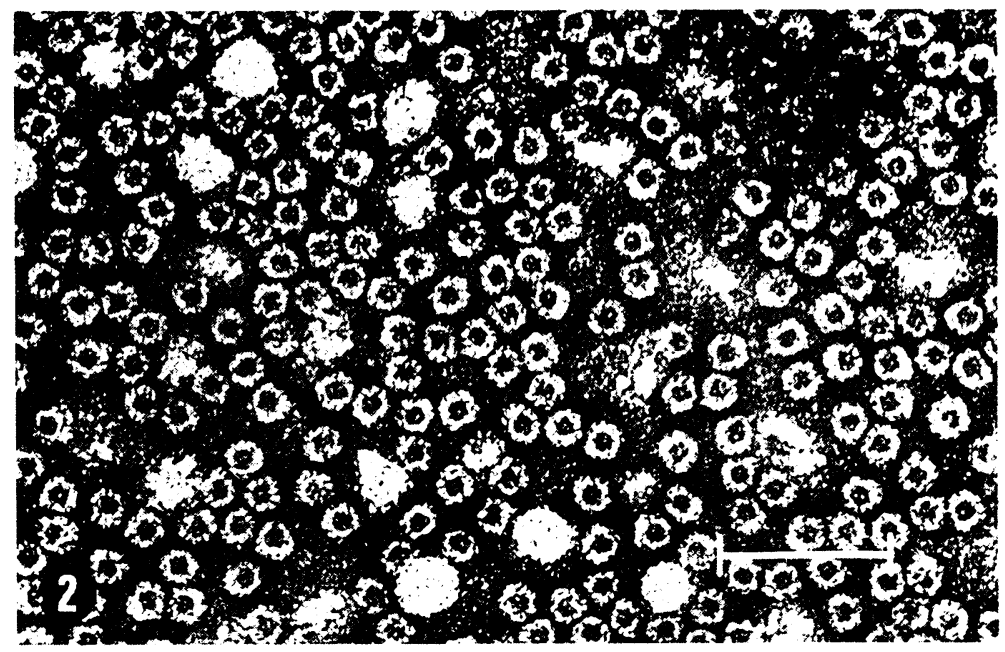

Fig. 2 Purified Phycomyces ferritin negatively stained with uranyl acetate. The electronopaque iron core is surrounded by an electron-lucent protein shell. $\times 340,000$. Bar $=500 \AA$.

(Fig. 2). The electron-opaque iron core (50-60 $\AA$ in diameter) is surrounded by an electron-lucent annulus of protein (105 $\AA$ diameter). Although similar in structure to plant and animal ferritins, Phycomyces ferritin contains maximally about one-half as much iron per unit protein and sediments, at $55 \mathrm{~S}$, more slowly than horse ferritin.

\section{INDUCTION OF FERRITIN SYNTHESIS BY IRON}

Growth of Phycomyces on medium supplemented with iron causes a marked increase in the level of iron in mycelium, sporangiophores, and spores. Figure 3 shows the iron content of spores with increasing iron in the growth medium. The additional iron is present in ferritin molecules (Fig. 6). The fiftyfold increase in ferritin iron is probably too great to be accounted for simply by addition of iron to unfilled ferritin molecules. Thus, the results suggest that de novo synthesis of apoferritin has occurred similar to the induction of apoferritin which has been shown in animal tissues in response to iron administration (Fineberg and Greenberg, 1955; Loftfield and Eigner, 1958; Saddi and von der Decken, 1965; Drysdale and Munro, 1966).

Ferritin isolated from iron-supplemented growth medium $(15 \mu \mathrm{g} / \mathrm{ml}$ iron) has a uniformly high S value (see above) and contains a full complement of iron. Ferritin isolated from Phycomyces grown on iron-poor medium $(0.1 \mu \mathrm{g} / \mathrm{ml}$ iron) is more heterogeneous and has a somewhat lower $\mathrm{S}$ value $(40-50 \mathrm{~S})$ indicating less iron per molecule.

The ferritin content of Phycomyces grown on limiting amounts of iron has not been investigated. The level of $0.1 \mu \mathrm{g} / \mathrm{ml}$ iron present as impurities in growth medium is somewhat more than the minimal requirement since normal mycelial growth and sporangiophore development occur. Media from which iron has been 


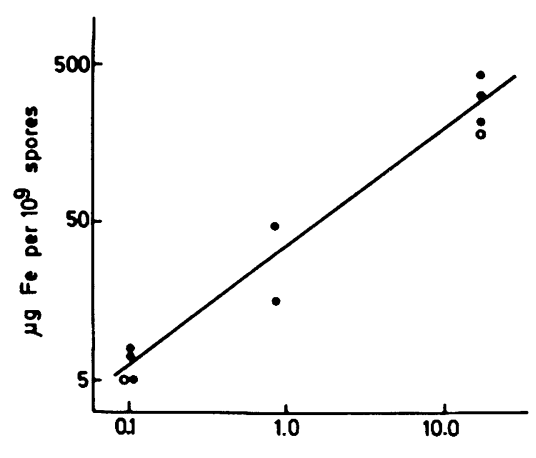

$\mu \mathrm{ge} / \mathrm{ml}$ growth medium

Fig. 3 Iron content of Phycomyces spores in cultures supplemented with iron. Phycomyces was grown on glucose-asparagine medium containing defined amounts of iron and ${ }^{50} \mathrm{Fe}$. Sporangiophores were harvested and spores isolated. The iron content per spore was calculated from the radioactivity per spore and the specific activity of ${ }^{50} \mathrm{Fe}$ in the medium. Each point represents an independent experiment. The two open circles show the results of direct chemical determination of iron spore (see David and Easterbrook, 1971, for details of iron determinations).

At least $50 \%$ of the spore iron in all samples is in ferritin molecules (see Fig. 6). Similar increases in iron and ferritin content occur in mycelium and sporangiophores when the growth medium is supplemented with iron.

completely removed support almost no mycelial growth and do not permit sporangiophore development (Odegard, 1952). Under such conditions spores containing more ferritin iron grow better than spores with less ferritin iron but the level of growth on iron supplemented medium is not attained (C. N. David, unpublished).

\section{FERRITIN SYNTHESIS AND LOCALIZATION}

\section{IN SPORES}

Ferritin can be isolated from all developmental stages of Phycomyces-mycelium, sporangiophores, and spores. In all cases it appears to be associated with lipid droplets. During the course of spore formation, sporangiophore ferritin is selectively incorporated into spores. In cultures grown on iron-poor medium, $80 \%$ of the total sporangiophore ferritin is found in spores and $20 \%$ remains in sporangiophore cytoplasm after spore formation. Dry weight is partitioned approximately equally between spores and sporangiophores. On iron-supplemented medium, where the level of ferritin is about fiftyfold higher, the partitioning of ferritin between spores and sporangiophore cytoplasm more nearly approaches the partitioning of dry weight.

Sporangiophore development is dependent on mycelial growth. Many of the components of sporangiophore cytoplasm and spores, e.g., nuclei, polyphosphates, and lipid droplets are taken up directly from the mycelium and are not synthesized in the elongating sporangiophore (Bergman et al., 1969; Galle, 1964). Some of these components are in fact synthesized in the mycelium prior to the initiation of sporangiophore outgrowth. Ferritin is synthesized in the mycelium and per- 


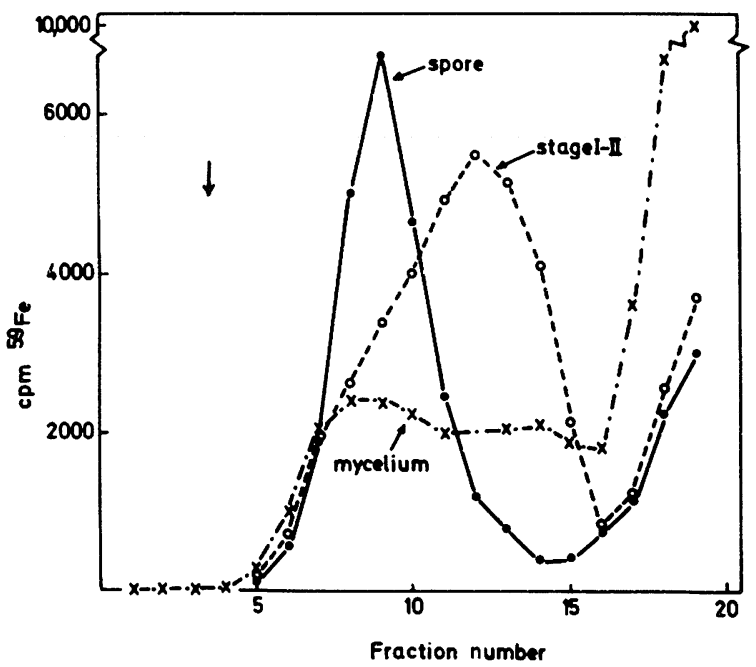

Fig. 4 Sucrose gradient sedimentation of ${ }^{59} \mathrm{Fe}$-labeled ferritin from mycelium, Stage I-II sporangiophores, and spores. Phycomyces was cultured on glucose-asparagine medium ( 0.1 $\mu \mathrm{g} / \mathrm{ml}$ iron) with ${ }^{50} \mathrm{Fe}$. Mycelium was harvested immediately prior to initiation of sporangiophores; stage I-II sporangiophores were harvested from a parallel culture 8 hours later; spores were prepared from a third parallel culture 1 day later. All three samples were homogenized with a Nossal disintegrator and extracted with $n$-butanol. Aliquots of the aqueous phase were sedimented in 5 to $20 \%$ sucrose gradients $\left(37,000 \mathrm{rpm}, 2.5\right.$ hours, $6^{\circ} \mathrm{C}$ ). Fractions were collected and assayed for ${ }^{59} \mathrm{Fe}$. Sedimentation is from right to left. The arrow indicates the position of a sedimentation marker at $81 \mathrm{~S}$. The results of all three gradients have been superimposed for comparison.

haps during the early stages of sporangiophore outgrowth. This ferritin has a broad spectrum of $S$ values (iron contents) in cultures grown on $0.1 \mu \mathrm{g} / \mathrm{ml}$ iron (Fig. 4). During sporangiophore initiation a large population of ferritin molecules of intermediate iron content is concentrated in the cytoplasm of young (Stage I) sporangiophores. Eighty percent of this ferritin is destined to be incorporated into spores. In conjunction with spore formation at the end of Stage I, ferritin undergoes a maturation process. Ferritin molecules of intermediate $\mathrm{S}$ value become more homogeneous and acquire a higher $\mathrm{S}$ value (Fig. 4). A similar addition of iron to mammalian ferritin has been shown in vivo (Drysdale and Munro, 1966) and in vitro (Macara et al. 1972).

\section{FERRITIN AND IRON METABOLISM IN GERMINATING SPORES}

The selective incorporation of iron and ferritin into spores of Phycomyces grown on iron-poor medium suggests that ferritin iron is a storage form of iron destined to be used for biosynthesis following spore germination. In the following it will be demonstrated that ferritin in germinating spores releases iron to a soluble pool and that the release of iron from ferritin is controlled by the cell. The results suggest further that the soluble iron pool is involved in biosynthesis. 


\section{A. The Soluble Iron Pool}

Phycomyces mycelium, sporangiophores, and germinating spores have a pool of soluble iron. Since ferric iron is quite insoluble at cellular $\mathrm{pH}$, this "soluble" iron is probably complexed with a low-molecular weight substance. Nothing is known of the nature of the chelator involved. Chelators of the sideramine type (Neilands, 1957) are not excreted by Phycomyces (Müller, 1968). However, no attempt has been made to identify sideramines in cellular homogenates containing soluble iron.

The soluble iron pool in Phycomyces has the following characteristics: (1) it is slowly dialyzable; (2) it is not precipitated by $5 \%$ trichloroacetic acid or by $n$-butanol extraction of cell homogenates; and (3) it does not sediment during ultracentrifugation at $100,000 \mathrm{~g}$ for 3 hours. Soluble iron is present in biosynthetically active parts of Phycomyces, namely, in growing mycelium, sporangiophores, and germinating spores. It is not present in dormant spores although the spores contain ferritin and other elements of sporangiophore cytoplasm. This result suggests that soluble iron may be an intermediate or donor of iron for macromolecular biosynthesis.

\section{B. Release of Ferritin Iron During Germination}

The availability of spores with varying ferritin contents and containing no soluble iron pool provides an experimental basis for studying the release of iron from ferritin associated with the initiation of biosynthetic activities following spore germination. Phycomyces spores labeled with ${ }^{59} \mathrm{Fe}$ and containing two different levels of iron-6 $610^{-9}$ and $3 \times 10^{-7} \mu \mathrm{g} /$ spore-were obtained (Fig. 3 ). At least $50 \%$ of this iron was extractable as ferritin in both cases (Fig. 6). The fate of ferritin iron during germination and early mycelial growth was investigated. Butanol extraction of cell homogenates precipitates most cellular proteins leaving ferritin and soluble iron as the only major ${ }^{59} \mathrm{Fe}$-containing components in the aqueous phase. Gel filtration of this material clearly separates ferritin and soluble iron.

Heat-shocked Phycomyces spores germinate rapidly and synchronously at $20^{\circ} \mathrm{C}$ in glucose-asparagine medium. The spores first swell and then build a large central vacuole. By 12 hours all spores are vacuolated and by 16 hours most have developed young germ tubes which grow out to become mycelium.

Ungerminated spores contain only iron extractable as ferritin. Following germination of ferritin-poor spores, extractable ferritin decreases and disappears almost entirely by 24 hours (Fig. 5). By comparison ferritin-rich spores show no detectable loss of ferritin. Figure 6 shows the quantitative results from several independent experiments. There is a rapid loss of ferritin between 12 and 20 hours after germination in ferritin-poor spores. Under the same conditions ferritin-rich spores show a slight increase in ferritin due to more efficient extraction of growing mycelium compared to spores. In the case of ferritin-poor spores the increased efficiency of extraction probably hides the initial stages of ferritin degradation since at 12 hours ${ }^{59} \mathrm{Fe}$ has already started to appear in the soluble pool. 


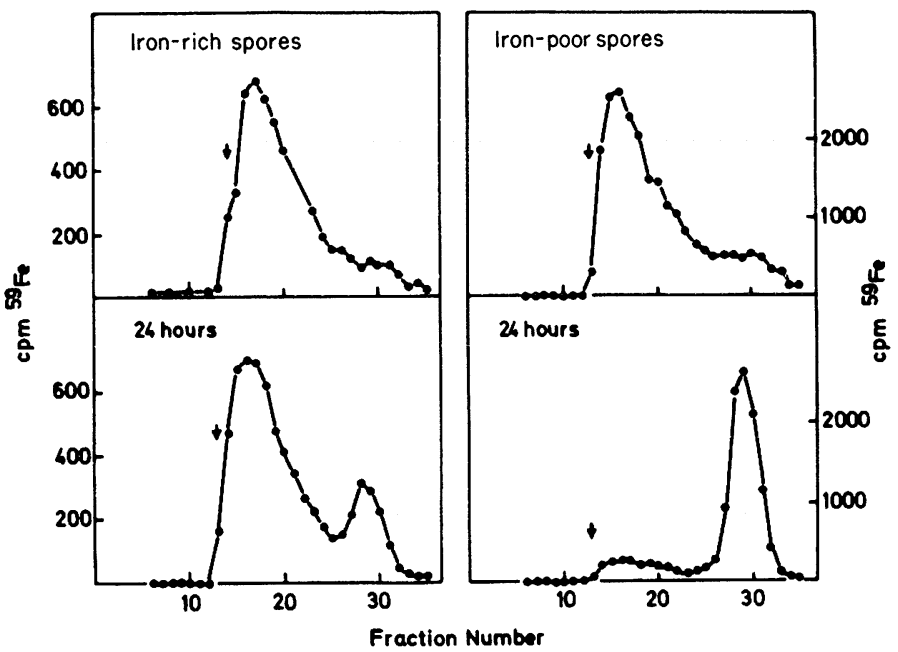

Fig. 5 Fate of ferritin iron during germination of ${ }^{50} \mathrm{Fe}$-labeled spores. Spores containing two different levels of ferritin iron and ${ }^{50} \mathrm{Fe}$ were prepared from iron-poor $(0.1 \mu \mathrm{g} / \mathrm{ml})$ and ironrich $(15 \mu \mathrm{g} / \mathrm{ml}$ ) cultures (see Fig. 3 for details). The labeled spores were heat-shocked and germinated in glucose-asparagine medium $\left(10^{6}\right.$ spores $/ \mathrm{ml}$ ) containing about $0.1 \mu \mathrm{g} / \mathrm{ml}$ iron. Samples were taken at 0 and 24 hours, homogenized in a Nossal disintegrator, and extracted with $n$-butanol. The aqueous phase was analyzed by gel filtration on an agarose column (Bio Gel A $1.5 M$; eluted with $0.05 M$ phosphate buffer, pH $6.0,0.15 M \mathrm{NaCl}$ ). The excluded volume is indicated by the arrow. Ferritin is partially included and elutes about fraction 16. Lowmolecular weight soluble iron is completely included and elutes about fraction 29.

Coincident with the loss of ${ }^{59} \mathrm{Fe}$ from ferritin in germinating ferritin-poor spores, is the appearance of ${ }^{59} \mathrm{Fe}$ at the position of soluble iron on the gel filtration column. Soluble ${ }^{59} \mathrm{Fe}$ begins to appear at 12 hours and increases rapidly up to 24 hours when most of ${ }^{59} \mathrm{Fe}$-ferritin has been degraded (Fig. 5). Following germination of iron-rich spores, ${ }^{59} \mathrm{Fe}$ appears in the soluble pool by 24 hours. A coincident decrease in the level of ferritin can not be demonstrated because of the increasing efficiency of extraction of germinated tissue compared to spores. Calculating from the specific activity of ${ }^{59} \mathrm{Fe}$ in the germinating spores, the pools of soluble iron at 24 hours were: $0.04 \mu \mathrm{g} / 100 \mathrm{mg}$ wet weight for germinated ironpoor spores and $0.3 \mu \mathrm{g} / 100 \mathrm{mg}$ wet weight for germinated iron-rich spores. The levels of ferritin iron remaining in the same tissue were 0.005 and $1.2 \mu \mathrm{g} / 100 \mathrm{mg}$, respectively, for ferritin-poor and ferritin-rich tissue.

The results show that (1) release of iron from ferritin occurs upon spore germination and (2) the extent of this release is controlled by the cytoplasm of the germinating spores. When the cytoplasm is saturated with iron, further release of ferritin iron is blocked. Emery (1971) and Winkelmann and Zähner (1973) have shown a similar saturation of cytoplasmic sites by sideramine iron taken into cells of Neurospora and Ustilago from the external medium. Above a defined intracellular concentration, the uptake of sideramine iron is blocked. Both results strongly suggest that control mechanisms regulate the level of cytoplasmic iron acquired either from an intracellular iron-storage molecule or from an extracellular source. 


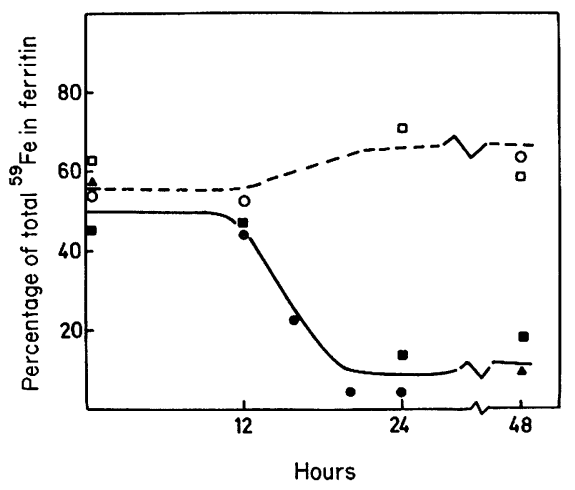

Fig. 6 Quantitative changes in ferritin iron during germination of ferritin-rich and ferritinpoor spores. The figure summarizes the results from three independent experiments of the type shown in Fig. 5. The ${ }^{50} \mathrm{Fe}$ extractable as ferritin is expressed as the percentage of total ${ }^{50} \mathrm{Fe}$ in the sample $\left(\%{ }^{50} \mathrm{Fe}\right.$ in ferritin peak after gel filtration of the aqueous phase $\times \%$ of total ${ }^{50} \mathrm{Fe}$ in the aqueous phase; see David, 1968). Filled symbols, ferritin-poor spores; open symbols, ferritin-rich spores.

\section{Mechanism of Iron Release from Ferritin}

The release of iron from ferritin during germination of ferritin-poor spores provides an opportunity to study the mechanism involved. In particular, by measuring the $S$ value (iron content) of the ferritin as a function of the amount of iron released, it is possible to determine if all molecules in the population are losing iron equally or if release is an "all-or-none" reaction in individual molecules. Figure 7 shows the sedimentation properties of the ferritin remaining after various degrees of iron release during the germination of ferritin-poor spores. During the rapid loss of ferritin iron no ${ }^{59} \mathrm{Fe}$-labeled ferritin molecules appear which sediment more slowly than spore ferritin. Thus, the release of iron from ferritin appears to occur in an all-or-none reaction.

This result eliminates simple models of iron release based on chelation (Pape et al., 1968) or reduction (Bielig and Bayer, 1955) in which all ferritin molecules are attacked statistically. These mechanisms would only yield the all-ornone result if the process in individual molecules were highly cooperative such that nucleation was the rate-limiting step or if the cytoplasm were compartmentalized into local regions where ferritin was being degraded and other regions where ferritin was protected. In either case, the release of iron from individual molecules must be a rapid process.

A more tempting explanation, in view of the all-or-none result, is the enzymatic degradation of ferritin-ferritin molecules being the substrate for an enzyme which releases iron from the core. Recently, evidence for such an enzymatic activity has been presented (Osaki and Sirivech, 1971) and Crichton (1973b) has suggested a mechanism, involving loss of protein subunits from the shell, by which the degrading enzyme could gain access to the iron core. It remains to be determined, however, if this enzymatic activity, in fact, causes all-or-none release of iron. Furthermore, the enzyme must be subject to feedback inhibition by cytoplasmic iron since its activity is clearly limited under conditions prevailing in germinating ferritin-rich spores. 


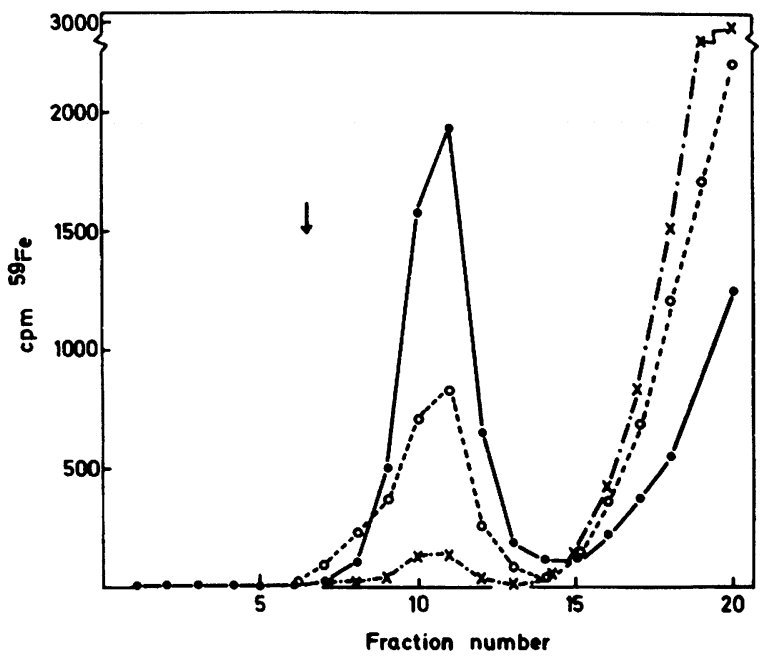

Fig. 7 Sucrose gradient sedimentation of ${ }^{59} \mathrm{Fe}$-labeled ferritin from germinating ferritin-poor

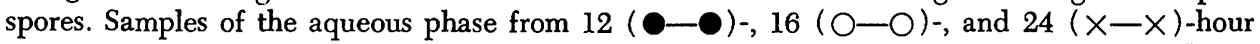
germinated ferritin-poor spores (Fig. 6) were sedimented in 5 to $20 \%$ sucrose gradients $\left(37,000 \mathrm{rpm}, 2\right.$ hours, $\left.6^{\circ} \mathrm{C}\right)$. Fractions were collected and assayed for ${ }^{80} \mathrm{Fe}$. Sedimentation is from right to left. The arrow indicates the position of a sedimentation marker at $81 \mathrm{~S}$. The results from the three gradients have been superimposed to facilitate comparison.

If the all-or-none result is indicative of the general mechanism of iron release from Phycomyces ferritin-not just a special mechanism associated with spore germination-then it must be concluded that ferritin molecules having intermediate $S$ values are the product of iron accumulation rather than the result of random release and addition of iron. Drysdale and Munro (1966) have demonstrated in rat liver that the synthesis of ferritin molecules occurs by slow accumulation of iron. Molecules of intermediate iron content are precursors to molecules of higher iron content. The changes in sedimentation properties of ferritin during spore formation in Phycomyces (Fig. 4) also suggest that molecules of intermediate iron content are precursors which take up more iron to form the final product-ferritin in spores.

\section{SUMMARY}

The iron-storage protein ferritin has been isolated from the fungus Phycomyces thus extending the range of occurrence of ferritin to microorganisms. Phycomyces ferritin is closely similar in structure to plant and animal ferritins and its synthesis is also stimulated by supplemental iron in the growth medium.

Ferritin iron is concentrated in Phycomyces spores. During spore germination the ferritin iron is released to a soluble iron pool which appears to be involved in biosynthetic processes utilizing iron. The amount of ferritin iron released is limited by the cell even in the presence of excess ferritin. The nature of this feedback control is not known. 
In Phycomyces the uptake and release of iron by ferritin appear to occur by different mechanisms. The release of iron during spore germination is an all-ornone process. By comparison, synthesis of full ferritin which occurs during spore formation involves slow accumulation of iron thus giving rise to molecules of intermediate $S$ value and iron content.

\section{ACKNOWLEDGMENTS}

I wish to thank Dr. E. W. Goodell and Dr. G. Winkelmann for their useful discussions during the preparation of this manuscript. The research was supported by National Science Foundation Grant GB-4642 and U.S. Public Health Service Grant GM-00086.

\section{REFERENCES}

Bergman, K., Burke, P. V., Cerda-Olmedo, E., David, C. N., Delbrück, M., Foster, K. W., Goodell, E. W., Heisenberg, M., Meissner, G., Zalokar, M., Dennison, D. S., and Shropshire, W. (1969). Bacteriol. Rev. 33, 99.

Bielig, H. J., and Bayer, E. (1955). Naturwissenschaften 42, 466.

Crichton, R. R. (1973a). Angew. Chem. 12, 57.

Crichton, R. R. (1973b). Brit. J. Haematol. 24, 677.

David, C. N. (1968). Ph.D. thesis, California Institute of Technology, Pasadena, California.

David, C. N., and Easterbrook, K. (1971). J. Cell. Biol. 48, 15.

Drysdale, J. W., and Munro, H. N. (1966). J. Biol. Chem. 241, 3630.

Emery, T. (1971). Biochemistry 10, 1483.

Fineberg, R. A., and Greenberg, D. M. (1955). J. Biol. Chem. 214, 97.

Fischbach, F. A., and Anderegg, J. W. (1965). J. Mol. Biol. 14, 458.

Galle, H. K. (1964). Protoplasma 59, 423.

Granick, S. (1946). Chem. Rev. 38, 379.

Harrison, P. M. (1964). Iron Metab. Intern. Symp. Aix-en-Provence, France, July, 1963. Springer-Verlag, Berlin.

Hyde, B. B., Hodge, A. J., Kahn, A., and Birnstiel, M. L. (1963). J. Ultrastruct. Res. 9, 248.

Loftfield, R. B., and Eigner, E. A. (1958). J. Biol Chem. 231, 925.

Macara, I. G., Hoy, T. G., and Harrison, P. M. (1972). Biochem. J. 126, 151.

Müller, A. (1968). Ph.D. thesis, Eberhard-Karls-Univeristät, Tübingen, Germany.

Neilands, J. B. (1957). Bacteriol. Rev. 21, 101.

Odegard, K. (1952). Physiol. Plant. 5, 583.

Osaki, S., and Sirivech, S. (1971). Fed. Proc. Fed. Amer. Soc. Exp. Biol. 30, 1292.

Pape, L., Multani, J. S., Stitt, C., and Saltman, P. (1968). Biochemistry 7, 613.

Peat, A., and Banbury, G. H. (1968). Planta 79, 268.

Saddi, R., and von der Decken, A. (1965). Biochim. Biophys. Acta 111, 124.

Sassen, M. M. A. (1965). Acta Bot. Neer. 14, 165.

Winkelmann, G., and Zähner, H. (1973). Arch. Mikrobiol. 88, 49. 